\title{
Contractures Complicating Spinal Cord Injury: Incidence and Comparison between Spinal Cord Centre and General Hospital Acute Care
}

\author{
Gary M. Yarkony, M.D., ${ }^{1}$ L. Mitchell Bass, B.A., ${ }^{1}$ Vernon Keenan, III $^{1}$ \\ and Paul R. Meyer, JR., M.D. ${ }^{2}$ \\ Midwest Regional Spinal Cord Injury Care System, Departments of Orthopedic \\ Surgery ${ }^{2}$ and Rehabilitation Medicine, ${ }^{1}$ Northwestern University, Chicago, Illinois \\ 60611, U.S.A.
}

\begin{abstract}
Summary
One hundred and eighty-one spinal cord injured patients admitted to the Rehabilitation Institute of Chicago after acute care following a spinal cord injury were studied. The presence or absence of contractures as well as significant abnormalities with loss of range of motion greater than $15 \%$ was recorded. Patients were either admitted from general hospitals or the acute care unit of our spinal centre, Northwestern Memorial Hospital. Patients treated in the general hospitals had a statistically significant increased incidence of contractures compared to spinal centre patients. Patients treated in the spinal centre were transferred to the rehabilitation hospital sooner post injury. An increased time from onset to rehabilitation admission correlated with a statistically significant increased incidence of contractures. Tetraplegic patients had a statistically significant increase over paraplegic patients and were more likely to have contractures of several upper extremity joints. Contracture development was not related to fractures of the extremities. This evidence further supports the need for spinal cord centres and provides data on the incidence of contractures in spinal cord injured patients which has not been reported previously. Key words: Spinal cord injury; Contractures; Rehabilitation; Paraplegia; Tetraplegia.
\end{abstract}

\section{Introduction}

The rehabilitation of the spinal cord injured patient and eventual reintegration into society is a task that is frequently delayed by numerous complications. These include medical, social, psychological or/and physical problems. The unique aspects of spinal cord management has led to the development of spinal units. Bedbrook (1980) has condemned the piecemeal care of spinal fractures with paralysis characterised by the occasional patient being treated by the occasional doctor. This argument was most recently strengthened in a comparison of medical 
complications in patients treated in specialised and non specialised centres. (Donovan et al., 1984).

Contractures are a well known complication of immobilisation. Their development in spinal cord injured patients has been recognised but not well studied. Gowers (1888) in describing the symptoms of spinal cord pathology noted three different aetiological factors in their development. These were nerve root impingement, spasm and muscle imbalance. Davis (1936) stressed the importance of active and passive movements in preventing deforming contractures stating that they invariably occur in an inactive or denervated muscle. Guttmann (1976) advocated passive movements of all joints at least three times daily to prevent contracture development and described how specific joint contractures can delay rehabilitation. Bedbrook (1981) has described the relationship of oedema paralysis, poor positioning and minute haemorrhages and trauma to their development and advocated prevention by one full range of motion to the joints daily and proper positioning.

Scott and Donovan (1981) have commented on the lack of literature on proper positioning in spinal cord injured patients. They suggested methods to prevent shoulder pain and contractures. Rivera-Dominguez et al. (1978) have described pes cavus and claw toe deformities in spinal cord injury, and described two practical aspects-difficulty in fitting shoes and increased susceptibility to pressure sores.

The purpose of this study is to further clarify factors related to contracture development. No data exists on the incidence of contractures in spinal cord injured patients. Of particular interest as well is a comparison of their development in patients treated acutely in spinal cord centres versus general (non-centre) hospitals. Other factors related to contracture development that have not been adequately studied are the relationship if any of their development to the level of the lesion, completeness of lesion and fractures of the extremities. This study was undertaken to answer these questions. It was hoped that in undertaking this study an increased awareness of contractures will develop thereby decreasing an important physical factor delaying rehabilitation of spinal cord injured patients.

\section{Methods and materials}

The records of one hundred and eighty-one spinal cord injured patients admitted to the Rehabilitation Institute of Chicago during a 2-year period were reviewed. The patients were transferred to the Rehabilitation Institute of Chicago from one of two referral sources. Patients were admitted from either the Northwestern Memorial Hospital (centre patients), the acute care unit of the Midwest Regional Spinal Cord Injury Care System of which the Rehabilitation Institute of Chicago is the rehabilitation unit or from the acute care units of non-spinal cord centre hospitals (non-centre patients). The centre patients were managed acutely by a physician specialising in spinal cord injury and managed throughout their acute care and rehabilitation by a physiatrist with expertise in spinal cord injury. A team of nurses and therapists with expertise in spinal cord injury are present in both the Northwestern Memorial Hospital and Rehabilitation Institute of Chicago to assure appropriate physical and medical management. Non-centre 
patients are spinal cord injured patients managed in general hospitals in units that are not dedicated solely to the care of spinal cord injured patients.

The records were reviewed to determine the lowest normal level of the lesion, completeness of the lesion, and Frankel classification. The time from onset to admission to the acute care unit at Northwestern Memorial Hospital and time from onset of injury to the Rehabilitation Institute of Chicago was recorded.

Measurement of passive joint range of motion is performed routinely as part of the admission evaluation to the Rehabilitation Institute of Chicago. It is performed using standard goniometric techniques and recorded on a standard form. Records were reviewed to determine the presence or absence of normal range of motion and to determine the presence of more significant abnormalities. Significant abnormalities were defined as either the loss of 15 per cent of passive motion in one key range or the loss of several degrees of motion in multiple joint planes. The criteria for a significant loss in the lower extremities is described in Table 1 and the criteria for a significant loss in the upper extremities is described in Table 2.

Fractures of the extremities were recorded to determine their relationship to contracture development.

The patient population consisted of 149 males $(82.3 \%)$ and 32 females $(17.7 \%)$. Average age for the males was 29.4 years and for the females 27.1 for an overall

Table 1 Criteria for a significant loss in range of motion of lower extremities

\begin{tabular}{lll}
\hline Joint & \multicolumn{1}{c}{ Motion } & \multicolumn{1}{c}{ Criteria } \\
\hline Hip & Flexion $20^{\circ}$ & \\
& Extension $5^{\circ}$ & Loss of $20^{\circ}$ flexion \\
& Adduction $10^{\circ}$ & or loss in three \\
& Abduction $23^{\circ}$ & Joint Planes each \\
& Internal Rotation $23^{\circ}$ & greater than degrees \\
& External Rotation $23^{\circ}$ & indicated \\
Knee & Flexion-extension & $20^{\circ}$ \\
Ankle & Plantar-Dorsiflexion & $10^{\circ}$ \\
Foot & Inversion-Eversion & $10^{\circ}$ \\
\hline
\end{tabular}

Table 2 Criteria for a significant loss in range of motion of upper extremities

\begin{tabular}{lll}
\hline \multicolumn{1}{c}{ Joint } & \multicolumn{1}{c}{ Motion } & \multicolumn{1}{c}{ Criteria } \\
\hline Shoulder Joint & Abduction & $20^{\circ}$ \\
Shoulder Joint & Internal Rotation & $15^{\circ}$ \\
Shoulder Joint & External Rotation & $15^{\circ}$ \\
Shoulder Complex & Extension & $7^{\circ}$ \\
Shoulder Complex & Flexion & $25^{\circ}$ \\
Shoulder Complex & Abduction & $25^{\circ}$ \\
Elbow & Flexion-Extension & $45^{\circ}$ \\
Forearm & Supination & $40^{\circ}$ \\
& Pronation & $40^{\circ}$ \\
Wrist & Flexion-Extension $10^{\circ}$ & Loss of $10^{\circ}$ Flexion Extension \\
& Ulnar Deviation $23^{\circ}$ & or combined loss in Ulnar-Radial \\
& Radial Deviation $10^{\circ}$ & motion each greater than degrees \\
Thumb & MP \& IP Motion & indicated \\
Index & MP, IP, DIP Motion & $100^{\circ}$ total loss \\
\hline
\end{tabular}


average of 28 years. Tetraplegic patients totalled 54 per cent and paraplegic 46 per cent. Ninety patients were centre patients and 91 were non-centre. Fifty-eight per cent had incomplete lesions and 42 per cent complete.

\section{Results}

Thirty-two joint motions were evaluated in one hundred and eighty-one patients. Twenty-six patients had a completely normal range of motion on admission to the Rehabilitation Institute. Normal motion was recorded for 4205 joint motions $(72.6 \%)$. Abnormalities in joint motion that were present but not large enough to meet the criteria delineated in Tables 1 and 2 were seen in 496 motions $(8.5 \%)$. Significant abnormalities meeting the criteria in Tables 1 and 2 were present in 866 motions (15\%). Data was not available on 225 motions (3.9\%). The average number of contractures per patient was 7.5 (S.D. 6.22 Median 6.0).

There were significant differences when comparing centre and non-centre patients. Centre patients had normal range of motion in 78 per cent of joint motions as compared to 68 per cent in non-centre patients. This difference was statistically significant at $\mathrm{p}<0.05$. Non-centre patients had mild abnormalities in 10 per cent of joint motions and significant abnormalities in 17 per cent, with 5 per cent not recorded. Centre patients had mild abnormalities in 7 per cent of their joint motions and significant abnormalities in 13 per cent with 2 per cent not recorded. Almost all centre patients (95\%, 77 of 81 patients) were admitted to the acute unit within 24 hours of injury. The time from injury to rehabilitation admission for both groups averaged 48.08 days (median 35.0, standard deviation 42.25). Average time to admission for centre patients was 29.9 days and non-centre patients was 66.25 days. This difference was significant at $p<0.01$. There was a significant relationship between the increased number of contractures per patient and time to rehabilitation admission $(p<0.01)$.

There were no significant findings when complete and incomplete lesions were compared.

When paraplegic and tetraplegic patients were compared there were significant differences with tetraplegics, especially $(p<0.01)$ with contractures of one elbow,

Table 3 Joint involvement comparing centre and non-centre patients

\begin{tabular}{|c|c|c|c|c|c|c|c|c|}
\hline \multirow[b]{3}{*}{ Joint } & \multicolumn{4}{|c|}{ Non Centre } & \multicolumn{4}{|c|}{ Centre } \\
\hline & \multicolumn{2}{|c|}{ Mild Abn } & \multicolumn{2}{|c|}{ Significant Abn } & \multicolumn{2}{|c|}{ Mild Abn } & \multicolumn{2}{|c|}{ Significant Abn } \\
\hline & $\mathbf{R}$ & L $\%$ & $\mathbf{R}$ & $\mathrm{L}$ & $\mathbf{R}$ & L $\%$ & $\mathbf{R}$ & $\mathrm{L}$ \\
\hline Hip & 35 & 36 & 36 & 33 & 34 & 27 & 22 & 29 \\
\hline Knee & 12 & 10 & 11 & 9 & 6 & 2 & 3 & 4 \\
\hline Ankle & 7 & 9 & 56 & 57 & 7 & 8 & 40 & 32 \\
\hline \multicolumn{9}{|l|}{ Shoulder Joint } \\
\hline Abduction & 7 & 3 & 9 & 10 & 2 & 4 & 12 & 16 \\
\hline Int Rotation & 8 & 8 & 29 & 23 & 11 & 8 & 24 & 22 \\
\hline Ext Rotation & 9 & 3 & 15 & 19 & 6 & 4 & 18 & 19 \\
\hline \multicolumn{9}{|l|}{ Shoulder Complex } \\
\hline Extension & 1 & 0 & 7 & 2 & 2 & 1 & 4 & 7 \\
\hline Flexion & 8 & 13 & 34 & 33 & 8 & 10 & 30 & 28 \\
\hline Abduction & 12 & 9 & 26 & 32 & 6 & 3 & 30 & 30 \\
\hline Elbow & 15 & 12 & 1 & 1 & 8 & 6 & 1 & 1 \\
\hline
\end{tabular}


the wrists, thumbs and index fingers. Tetraplegic patients had a significantly increased incidence of contracture $(p<0.1)$.

The joints most commonly affected overall are summarised in Table 3.

There were no significant differences between patients based on Frankel classification (completeness of lesion).

When comparing individual joints in centre and non-centre patients there were significant differences between the two groups. Non-centre patients were more likely to have contractures of one hip, both knees and both ankles $(p<0.01)$. This was analysed by scoring each joint zero for normal, one for mild abnormalities and two for significant abnormalities and comparing the average score using the separate variance estimate $\mathrm{T}$-value.

There were 30 fractures involving the extremities or clavicle in 28 patients. Nine patients sustained rib fractures. The joints proximal and distal to the fracture site in the affected and non-affected extremity were compared to determine if there was an increase in abnormalities on the side with fractures. There were eight abnormalities in joints proximal or distal to the fracture site that did not have corresponding abnormalities on the unaffected side. Seven were significant abnormalities and one was not. Five of these were abnormalities of motion in a paraplegic non-centre patient's shoulder with a clavicular fracture. Conversely there were four abnormalities on the contralateral side to fractures that were not present on the fractured side. Coexisting fractures had little effect on contracture development except in the one patient described.

\section{Discussion}

This study provides further evidence of the improved physical condition of the spinal cord injured patient when treated in a spinal cord centre with a coordinated system of care. It should also serve as a guide for those caring for these patients on an infrequent basis. The development of joint contractures is an area that receives little attention in the medical literature and all too often in clinical care in spite of the physiological and functional changes that occur when contractures are present.

In the normal maintenance of the body there is a continuous turnover of connective tissue. Frequent motion maintains the loose areolar connective tissue and collagen meshwork which will shorten to the length it is stretched (Kottke, 1966). Adhesive forces that bind muscle increase up to 11 per cent during denervation due to factors in the gound substance. (Stolov et al., 1974).

Biochemical changes occur in the immobilised contracted joint. Total hexosamine content is diminished and this correlates with joint stiffness and the energy required to flex and extend experimental joints (Woo et al., 1975). Motion provents anomalous cross links between collagen fibres and maintains proteglycans which entrap water and maintain lubrication. There is no muscle fibre loss in atrophy produced by external immobilization (Cardenas, 1977).

Enneking and Horowitz (1972) have described the intraarticular effects of immobilisation on the human knee. There is a progressive contracture of the joint capsule and pericapsular structures with a concomitant increase in intraarticular fibrofatty tissue. With time this progresses to an obliteration of the joint space and development of fibrous connective tissue. 
Frank et al. (1984) have stated that 'contractures may best be treated by prevention a concept that is now only receiving adequate attention'. Range of motion exercises should be initiated upon admission. One full range of motion for each joint daily may be satisfactory but the best guide is the patient's clinical response. This may be supplemented by splinting, casting and local nerve blocks where indicated to facilitate range. Prolonged stretch of moderate tension is still the basis for contracture management. (Kottke et al., 1966) Heat when combined with stretch followed by a maintenance of stretch during cooling with further facilitate restoration of joint motion (Lehmann et al., 1970). When conservative management fails Bedbrook (1981) has recommended simple cutaneous surgical methods of contracture release.

The clinical significance of joint contractures cannot be over-emphasised. Contractures can interfere with cosmesis, nursing care or functional activities. Therefore they must be prevented in all joints irregardless of the projected neurological outcome.

\section{Résumé}

Cent quatre vingt un patients bléssés à la moelle épinière, admis au Centre de Rééducation de Chicago (Rehabilitation Institute of Chicago) après des soins intensifs subis à la suite d'une lésion à la moelle épinière, ont été étudiés. La présence ou l'absence de contractures, aussi bien que des anomalies significatives de perte dans les possibilités de mouvement plus grande que $15 \%$, ont été reportées. Les malades ont été admis soit d'hôpitaux généraux soit d'unité de soins intensifs de notre centre spinal de l'Hôpital Northwestern Memorial. Parmi les malades soignés dans les hôpitaux généraux on a relevé statistiquement un nombre significativement plus élevé de cas de contractures que parmi les malades du centre spinal. Les malades soignés dans un centre ont été transferrés à l'hôpital de rééducation après l'accident plus tôt. L'augmentation de la durée écoulée entre l'attaque et l'admission pour la rééducation a été mise en corrélation avec une augmentation des cas de contractures statistiquement significative. Cette augmenation est plus importante chez les malades quadriplégiques que parmi les paraplégiques, les premiers étant plus sujets aux contractures des articulations des extrémités supérieures. Le développement des contractures n'a pas été mis en relation avec des fractures de ces extrémités. Cette évidence donne un appui supplémentaire aux centres de la moelle épinière et fournit des données sur l'incidence des contractures chez les malades de la moelle épinière, information qui n'avait pas été signalée jusque là.

\section{Zusammenfassung}

Einhunderteinundachtzig . Rückenmarkverletzte Patienten die zum Rehabilitation Institute von Chicago nach akuter Rückenmarkverletzung behandelt waren, wurden in dieser Studie erfasst. Mit und ohne Kontrakturen sowie auch erhebliche Abnormalitäten mit Verlust in Bewegung von mehr als $15 \%$ wurden festgestellt. Patienten die aufgenommen waren kamen von allgemeinen Hospitälern sowie auch vom akuten spinalen Behandlungszentrum, Northwestern Memorial Hospital. Patienten die in allgemeinen Hospitälern behandelt waren, hatten statistisch gesehen bedeutend erhöhtes Auftreten von Kontrakturen im Vergleich zu denen die im Spinalen Zentrum behandelt wurden. Patienten die im Spinalen Zentrum behandelt waren sind viel früher nach der Verletzung zum Rehabilitation Hospital überführt worden. Der grössere Zeitraum von der Verletzung bis zur Übermittelung zur Rehabilitation sind in Wechselbeziehung mit dem Statistisch bedeutend erhöhten Auftreten von Kontrakturen. Die Kontrakturen bei Quadriplegischen Patienten waren statistisch gesehen bedeutend höher als bei Paraplegia. Diese Kontrakturen waren in verschiedenen Gelenken der oberen Extremitäten. Die zugezogenen Kontrakturen bezogen sich nicht auf Knochenbrüche der Extremitäten. Dieser Beweis unterstützt die Notwendigkeit für mehr Spinale Zentren und gibt uns Daten über das Auftreten von Kontrakturen in Rückenmarkverletzten Patienten welche nicht vorher berichtet wurden.

\section{References}

BEDBRook SiR G, SEDGLEY GI 1980 The management of spinal injuries-post and present. Int Rehab Med 2:45-61. 
BEDBROOK SIR G 1981 The care and management of spinal cord injuries. Springer-Verlag, New York p. 219-221.

CARDENAS DD, Stolov WC, HaRdy R 1977 Muscle fiber number in immobilization atrophy. Arch Phys Med Rehabil 58:423-426.

Davis L 1936 Neurological surgery. Lea \& Febiger, Philadelphia p. 244-246.

Donovan WH, Carter RE, Bedbrook SIR G, Young JS, Griffiths ER 1984 Incidence of medical complications in spinal cord injury: patients in specialised, compared with nonspecialised centres. Paraplegia 22:282-290.

ENNEKING WF, HoRowitz M 1972 The intra-articular effects of immobilization on the human knee. J Bone Joint Surg 54A: 973-985.

Frank C, Akeson WH, Woo SL, Amiel P, Coutts RD 1984 Physiology and therapeutic value of passive joint motion Clin Orthop 185:113-125.

GOWERS WR 1888 A manual of diseases of the nervous system. P. Blakiston, Philadelphia, p. $154-155$.

GUTTMANN SIR L 1976 Spinal cord injuries-comprehensive management and research. Blackwell Scientific Publications, Oxford, p. 565-569.

KoTTKE FJ 1966 The effects of limitation of activity upon the human body. JAMA 196:117-122.

Kottke FJ, Pauley DL, PtKa RA 1966 The rational for prolonged stretching for correction of shortening of connective tissue. Arch Phys Med Rehabil 47:345-352.

LEHMANN JF, MASOCK AJ, WARREN CG, KABLANSKI JN 1970 Effect of therapeutic temperatures on tendon extensibility. Arch Phys Med Rehabil 51:481-487.

Rivera-Dominguez M, DiBenedetto M, Frisbie JH, Rossier AB 1978 Pes cavus and claw toes in patients with spinal cord injury and multiple sclerosis. Paraplegia 16:375-382.

ScotT JA, DonovaN WH 1981 The prevention of shoulder pain and contracture in the acute tetraplegic patient. Paraplegia 19:313-319.

Stolov WC, Fry LR, Riddell WM, WeIlepp TG JR 1974 Adhesive forces between muscle fibers and connective tissue in normal and denervated rat skeletal muscle. Arch Phys Med Rehab 154:208-213.

Woo SL, Mathews JV, Akeson WH, Amiel D, Convery 1975 Connective tissue response to immobility Arthritis Rheum 18:257-264. 